\title{
Personality traits/disorders. Sleep disorders
}

COMPARATIVE CHARACTERISTICS OF TRANQUILLIZERS' ACTION IN NEUROTIC SLEEP DISTURBANCES

Yuri A. Alexandrovsky

Serbsky National Research Centre for Social and Forensic Psychiatry, Kropotkinsky per. 23, 119034, Moscow, Russia

12 most frequently used tranquilizers were studied in- and outpatients in order to elucidate comparative patterns of tranquillizer therapeutic action in neurotic night sleep disturbances. An original multifactorial quantified system of therapeutic action was employed in dynamic evaluation of patients mental an psycho-physiologic state as well as of pre-, intra- and postsomnic disorders. It was established that both hypnotic proper and general tranquillizing (anxiolytic) influences owe to the therapeutic action in neurotic sleep disturbances. The most powerful antineurotic action proper to phenazepam, lorazepam and alparazolam is not accompanied with equal hypnotic effects. Tranquillizing action, however, serves a groundbase for effective somnolence. Differential indications for nitrazepam, flunitrazepam, imovan and estazolam administration in various clinical forms of neurotic sleep distubances are proposed.
HETEROGENEITY OF EATING PATTERNS AMONG OBESE PATIENTS

J.P. Kahn* A. Collignon**, M. Laxenaire*, L. Méiean**

* Department of Psychiatry, Nancy University, Hôpital Jeanne d'Arc, 54201 Toul France, and "* INSERM U 308, 38 rue Lionnois, 54000 Nancy, France

It is only recently that the heterogeneity and complexity of obesity has been recognized and investiged. Impairement of the energy balance, or nutritional status, as well as inappropriate eating behaviour contribute to its multifactorial aetiology and its chronicity. SUBJECTS : 22 female obese patients, hospitatized for their first weight-loss program were compared to 16 normal weight, hospitalized female patients, matched for age and socioeconomical status ; All subjects were free of severe organic or psychiatric illness. METHODS: A desciptive study was set up to investigate various amanmestic, clinical, nutritional, and behaviour features. Carrefull familial and personal history was recorded and various physical parameters, including weight and Body Mass Index (BMI) were assessed. A recall dietary survey investigated qualitative and quantitative data on eating habits, food preferences and associated psychological features. BESULTS : Both groups differed significantly, with regard to $B M I$ : $(32.2 \pm 5.1$ vs. $23.9 \pm 4.0$ ), the history of family and childhood obseity. No differences in total caloric intake between both groups could be found, although they exhibited very different eating patterns and sujective feelings. Obese patients appeared to be heterogeneous in respect to specific cravings. 
THERAPEUTIC ASPECTS OF ALCOHOLIC PSYCHOSES

B Lang, D Dakić-Koretic, D Buljan

Department of neurology, psychiatry, alcoholism

and other dependencies University Cilnic "Sestre milosrdice" Vinogradska c. 29,41000 Zagreb, CROATIA

Alcohollc psychoses are the most serious compitcation of excessive, long-term alcohol abuse. They are classiried into the group of acute exogenous reactive type psychoses. Laboratory tests indicate the toxic component of the disease, the same as the whole clinical picture. These are usually emergency cases, very often the patients' lives are endangered and are admltted in the intensive care unit. This requests accurate clinical and laboratory examination as well as an adequate directed drug therapy. Follow-up of the incidence of alcoholle piychoses among alcohollcs can serve also in the assesment of the efflclency of alcohol prevention and control programmes at the level of the community and on the wider levels. Statistical data of Treated Alcoholics indicate the tendency of decrease of the number of alcohollc psychoses in one organizating alcohol prevention and control programmes at the level of the community. The authors present in this paper the contemporary approach to the treatment of alcoholic psychoses.
EATING DISORDERS MINIMULT 78 AND PSYCHOPATHOLOGY IN A 82 WOMEN SAMPLE

(E. Lang. J. Pellet. M. Pichon. C. Montpeyroux, C. Coerchon, B. Estour)

Service Universitaire de Psychiatrie, 42055 Saint-Etienne Cédex 2, France.

82 eating disordered (ED) women $(21,5 \pm 5,3 \mathrm{yrs} ; \mathrm{BMI}=16,3 \pm 3,3)$ completed the EAT, the EDI the SCL 90 and the Minimult $78(\mathrm{M})$ and were studied by structured interview and AMDP (depression score : $13,7 \pm 7,9$ ).

All met ICD 10 criteria for restrictive anorexia nervosa (AN$; \mathrm{N}=38)$; $A N$, bulimic subtype $(\mathrm{AN}+; \mathrm{N}=22)$; normal weight bulimia (BN-;N=13); not otherwise specified ED $(\mathrm{N}=9)$.

For the 82 patients all $M$ subscale scores are comprised inside \pm 2sd respect to average.

Nevertheless we observed for subgroups :

\begin{tabular}{|c|c|c|c|}
\cline { 2 - 4 } \multicolumn{1}{c|}{} & $\begin{array}{c}\text { Depression } \\
\text { subscales }\end{array}$ & $\begin{array}{c}\text { Psychasthenia. } \\
\text { Subscales }\end{array}$ & $\begin{array}{c}\text { Schizophrenia } \\
\text { Subscales }\end{array}$ \\
\hline BN- & $70,8 \pm 8.8$ & $74.2 \pm 2,3$ & \\
\hline AN->18yrs & & $74 \pm 13,4$ & $72,6 \pm 14,2$ \\
\hline $\begin{array}{c}\text { Vomiting } \\
\text { AN+ and BN- }\end{array}$ & $71 \pm 9,4$ & $74,2 \pm 12$ & $74,5 \pm 13$ \\
\hline AN- and AN+ & $70 \pm 17$ & $76,5 \pm 12,5$ & $75,7 \pm 14$ \\
\hline
\end{tabular}

$A N+$ and $A N-$ differ (U test) for hysteria $(p=0,05)$, psychopathy $(p=0,04)$, schizophrenia $(p=0,001)$, and mania $(p=0,004)$ subscales.

Age, duration of illness and bulimic features have probably to do with psychopathological profiles. Comparaison with patients at the time of their first episode would be fruitful.
INSOMNLA DISORDER, ITS PREVALENCE ON THE METROPOLITAN AREA OF MONTREAL

\section{Ohayon. M Caulet. L Foumier}

Centre de recherche-Institut Philippe Pjnel de Montréal, 10905 boulevard HenriBourassa Est, Montréal, Québec, Canada, HlC $1 \mathrm{H} 1$

An epidemiological survey on sleeping disorders was conducted in 1993 on the Metropolitan area of Montreal. The target population concerned French speaking people of 15 years of age or more (1 761121 inhabitants). A representative sample of 1723 was obtained following the solicitation of 2117 persons. The acceptance rate was $81.4 \%$. Interviews were performed by phone using an exper system (EVAL). All results were calculated with confidence intervals of $95 \%$. Insomnia disorders, defined by the consumption of a medication to favour sleep OR unsatisfactory quality of sleep (UQS), were found for $17.8 \%$ of the subjects (W: $19.5 \% \pm 2.6 ; \mathrm{M}: 15.9 \% \pm 2.5$ ). Logistic regression was carried out with the presence of UQS as the dependent variable, sociodemographic characteristics, sleep habits and social life as independent variables. For the whole sample, results show that being separated, divorced or widowed $(\mathrm{p}<0.01)$, to take more than 15 minutes to fall asleep $(p<0.05)$, to have a sleep duration less than 7 hours $(p<0.001)$, to wake up regularly during the night ( $<<0.0001)$, to have a light $(p<0.0001)$ or average sleep ( $<<0.05$ ), being suffering of a physical illness $(p<0.05)$, to have consulted a physician within the last 6 month period $(p<0.05)$, to have an unsatisfactory social life $(p<0.01)$ and unsatisfactory friendship relations $(p<0.05)$ are significantly associated with the presence of UQS.

As regard consumption of psychotropic drugs, among the whole sample, $3.8 \%$ said to take a medication to favour their sleep (M: $2.8 \% \pm 1.1 \% ; \mathrm{W}: 4.7 \% \pm 1.4$ ). In fact, they truly used: hypnotics, $0.8 \%$; anxiolytics, $2 \%$; others, $1 \%$. Also, $3 \%$ of the population said to take a medication for anxiety: $1.6 \%$ take an anxiolytic, $0.8 \%$ other psychotropic drugs and $0.6 \%$ other non psychotropic drugs. When these both consumption are combined, we find that $5 \%$ of the population take a psychotropic drug: $3.3 \%$ take an anxiolytic; $0.9 \%$ a hypnotic; $0.1 \%$ both of these drugs; $0.7 \%$ other psychotropic drugs. Most of them take the psychotropic drugs since more than 6 months $(75 \%)$.

Prevalence of UQS is quiet the same than other similar studies. Rate of consumption of psychotropic drugs is also comparable with those found in North America. However, it is twice lower than what we got in a similar study conducted in France (10.7\%). It is not really surprising since considerable differences exist in Health Care Systems.

ALEXITHYMIA IN PATIENTS WITH ANXIETY DISORDERS : STATE AND TRAIT CHARACTERISTICS

Ch. Papageorgiou, A.D. Rabavilas, G. Trikkas, N. Vaidakis Athens University Medical School Department of Psychiatry, Eginition Hospital, 74 Vas. Sophías Ave., 11528 Athens, Greece.

Alexithymia comprises a constellation of characteristics (impoverished fantasy life, difficulty in using appropriate words to describe feelings, diminished capacity to dream, urgency to act and operational thinking) that have been classically attributed to mechanisms (affect deficit) underlying the development of a psychosomatic illness, in contrast to those subserving neurotic affective and cognitive functioning. However, in recent reports the non-neurotic nature of alexithymia has been critisized on the grounds that (a) higher levels of alexithymia were found in neurotic and delusional patients than in psychosomatic patients and (b) alexithymic patients appear to follow the arousal model proposed for anxiety neurotics. In this context, this study investigates the relation of alexithymia to "state" and "trait" factors in patients with anxiety disorders.

171 patients ( 89 females, 82 males, age range 24-45 years) suffering from anxiety disorders (generalized anxiety, $n=52$, $0 C D, n=49$, panic disorder, $n=38$ and phobic disorder, $n=32$ ), selected according to DSM III-R criteria, were administered the revised Shalling-Sifneos Personality Scale (SSPS-R) as well as a battery of clinical and personality scales, 54 of total patients ( $31.6 \%)$ demonstrated marked alexithymia. These patients were compared with the remaining 117 on a number of clinical and personality variables. Alexithymic patients, with the exception of "psychoticism" $(P<0.005)$, failed to be differentiated from the non-alexithymic group. The findings of this study indicate that alexithymia is a by no means rare manifestation in anxiety disorders. Alexithymic patients share similar "state" and "trait" characteristics with non-alexithymic patients. It is therefore concluded that the non-neurotic nature of alexithymia is not supported by these findings, while a re-examination of the mechanisms collectively referred to as "alexithymia" should be dealt with in. a more detailed and theoretically sound way in future research. 
PSYCHOLOGICAL AND SOCIAL CHARACTERISTICS OF ADULT CARRIERS AND NON-CARRIERS OF THE GENE FOR HUNTINGTON'S DISEASE APPLYING FOR GENETIC TESTING

NK Rosenberg', SA Sørensen ${ }^{2}$ A-L Christensen ${ }^{3}$

1 University Hospital of Aarhus, Dept. of Clinical Psychology, Skovagervej 2, DK-8240, Risskov, Denmark and

2 Institute of Medical Biochemistry and Genetics, University of Copenhagen, Panum Institute 24,4, Blegdamsvej 3, DK-2200 Copenhagen, Denmark.

${ }^{3}$ Center for Rehabilitation of Braindamage, University of Copenhagen, Njalsgade 88, DK-2300 Copenhagen.

Since 1989 presymptomatic DNA-testing for Huntington's Disease (HD) has been offered at Institute of Medical Biochemistry and Genetics, University of Copenhagen, from September 1993 as a direct gene-test. The first forty persons at risk for $\mathrm{HD}$ who were DNA-tested, were also assessed for 1) social characteristics and psychiatric symptoms, 2) attitudes towards $\mathrm{HD}$ and implications of genetic testing, and 3) psychological, mainly cognitive, functions. The persons at-risk had not developed manifest symptoms of $\mathrm{HD}$. Questionnaires, rating scales, and psychological tests were applied by investigators, who were blind to diagnosis.

Results: The group of persons at risk covered a wide area of sociodemographic characteristics, and very few differences between gene carriers and non-carriers were observed. No differences between groups were found with respect to psychiatric symptomatology or attitudes. Psychological tests, however, showed significantly worse cognitive functioning in the group of carriers.

\section{POSTTRAUMATIC NIGHTMARES AFTER FORTY YEARS \\ Bas J.N. Schreuder \\ Centrum '45, Rijnzichtweg 35, 2342 AX Oegstgeest, The} Netherlands.

Why do some people evolve repetitive posttraumatic nightmares after more than 40 years, whereas others do not? Method: Victims of world war II and Dutch veterans with war experiences from 1945-1952 $(n=63)$ participated in this study. They all applied for psychiatric treatment in Centrum 45. The initial screening included a clinical psychiatric interview and questionnaires (IES, Zung, SCL90, Life Events), and a semistructured interview aimed at PTSD, sleep, dreams and nightmares. A few months later they were asked to fill in a questionnaire just after waking up during 28 consecutive days.

Results- Two subgroups of posttraumatic nightmares could be differentiated: one in which 'replication' of the traumatic event predominates and another in which 'symbolization' predominates. The two subgroups were significantly related with different types of traumatization. The 'replication' subgroup was significantly related with the phenomenon of repetition of the contents.

Conclusion- The differentiation in two subgroups of posttraumatic nightmares is related to the kind of traumatization thus indicating different underlying neuropsychological and psychodynamic processes. The difference has consequences for the prevention and treatment of severely traumatized people.

\section{PSYCHIATRISCHE KOMORBIDITÄT BEIM SCHLAF-APNOE SYNDROM}

Weeß, H.-G. ${ }^{1}$, Rohmfeld, R. ${ }^{1}$, Steinberg, R. ${ }^{1}$, Pritzel, M. ${ }^{2}$

1 = Pfalzklinik Landeck, Weinstr. 100, D-76889 Klingenmünster, Germany

2 = University Koblenz-Landau, Dept, Landau, D-76829 Landau, Germany

Beim Obstruktiven Schlaf-Apnoe Syndrom (OSAS) wird neben einer reduzierten Leistungsfähigkeit am Tage auch von veränderten sozialen Interaktionen und

Persönlichkeitsveränderungen berichtet. Die Ursache wird in der nächtlichen Schlaffragmentierung infolge respiratorischer Arousals und / oder in den Apnoe-bedingten nächtlichen Hypoxämien gesehen.

Cartwright und Knight (1987) berichten von eingeschränkten familiären Beziehungen und einer Fehlanpassung an die Elternrolle sowohl bei SAS-Patienten als auch deren Lebenspartnerinnen. Klonoff et al. (1987) berichten über Schwierigkeiten am Arbeitsplatz und in der Partnerbeziehung, die nach erfolgreicher UPP größtenteils nicht mehr beobachtbar sind. In zahlreichen Untersuchungen wird aufgrund erhöhter Werte in den Skalen Depression, Hysterie und Hypochondrie des MMPI (Minnesota Multiphasic Personality Inventory) auf eine depressive Störung im Rahmen des OSAS geschlossen (z.B. Bearpark et al., 1987; Kales et al., 1984).

Eigene Untersuchungen an $n=10$ OSAS Patienten vor und nach nCPAP-Therapie legen jedoch die Vermutung nahe, daß es sich bei den Ergebnissen des MMPI und ähnlichen klinischen Fragebogendaten aufgrund der Symptomüberlappung beider Störungsbilder um einen testpsychologischen Artefakt handelt. Gestütz wird diese Hypothese durch eigene FPI (Freiburger Persönlichkeits Inventar)-, BEB (Beschwerdenerfassungsbogen)-, und MMPI -Daten, ebenso durch die Kriterien des diagnostischen Manuals DSM-III-R. 